\title{
Contesting Market-Based Conservation: Payments for Ecosystem Services as a Surface of Engagement for Rural Social Movements in Mexico
}

\author{
Elizabeth Shapiro-Garza \\ Nicholas School of the Environment \\ Duke University \\ elizabeth.shapiro@duke.edu
}

\begin{abstract}
The Mexican National Payment for Ecosystem Services (PES) programs, which provide financial incentives for rural landholders to conserve forest, were originally designed under the logic of market-based conservation. Based on a multi-sited, multi-scalar ethnography of the Mexican national PES programs, this article examines the process through which a national rural social movement was able to redefine the market-based narrative of PES, the historical and political context that provided this window of opportunity, and the ways in which their engagement led to a hybridization of the policy itself. The involvement of the rural social movement introduced a very different conception of PES - as a recognition by Mexico's federal state and urban society of the value of campesino environmental stewardship and an economic support to allow them to remain on the land. Their direct involvement in the redesign of the programs had a significant impact on their conformation that reflected this vision of revaluing the rural: the inclusion of agroforests and sustainably managed timber lands; requirements for self-defined forest management plans; provision of dedicated funding for technical assistance; and the training of local extensionists. I believe that in mapping the evolution of the Mexican national PES program we can begin to see how, in this particular place and time, rural social movements employed PES as a "useful surface of engagement" (Escobar 1999, p. 13) for contesting the market-based notions of the federal state, international lending institutions and conservation NGOs. I position this analysis in the context of the global project of "grabbing green" and as an example of the frictions that can inhibit and even partially reverse the logic of the seemingly inexorable rise of market-based conservation policy and projects.
\end{abstract}

\section{Keywords:}

market-based; environmental policy; payments for ecosystem services; rural social movements; Mexico; Latin America. 


\section{La Disputa sobre la Conservación Basado en el Mercado: Los Pagos por Servicios Ambientales como Superficie de Articulación para los Movimientos Sociales Rurales en México}

\section{Resumen:}

Los programas nacional de México para los pagos por servicios ambientales (PSA), que proveen incentivos financieros a propietarios rurales conservar su bosque, fue diseñado en base a un modelo de conservación basado en el mercado. Basado en una etnografía del programa Mexicano de PSA en mútiples sitios y a multiples escalas, este artículo examina el proceso a través del cual un movimiento social rural pudo redefinir la narrativa de mercado del PSA, el contexto histórico y político que facilitó este cambio, y las formas en que la participación del movimiento dio lugar a una hibridación de la política de PSA. La participación de este movimiento social rural introdujo una concepción distinta al PSA: como un reconocimiento por parte del gobierno federal de México y la sociedad urbano del valor del manejo sostentable de los campesinos y el soporte económico necesario para permitir que los campesinos se queden en sus territorios. La participación directa de los miembros del movimiento en la reformulación de los programas PSA tuvo un impacto significativo en su diseño en formas que reflejo su visión de "revalorar el campo": la inclusión de los sistemas agroforestales y los bosques bajo manejo activo para producción de madera, la definición autónoma de los planes de manejo forestal, la asignación de fondos específicos para asistencia técnica y la capcitación de profesionales 'extensionistas' locales. Al mapear la evolución de los programas Mexicano de PSA, se puede notar cómo, en este lugar y en este momento particular, los movimientos sociales rurales utilizaron al PSA como una "superficie útil de articulación" (Escobar 1999: 33) para disputar la supremacía de políticas ambientales basados en mercados como fue promovidos por el gobierno federal, los bancos multilaterales de desarrollo y las organizaciones no gubernamentales de conservación. Este análisis debe ser realizado en el contexto del proyecto global de 'saqueo verde' y como ejemplo de las fricciones que pueden inhibir, e incluso revertir parcialmente, la lógica del aparentemente inevitable ascenso de la conservación basado en el mercado.

\section{Palabras claves:}

pro-mercado, pol.tica ambiental, pago por servicios ambientales, movimientos sociales rurales, México, Latinoamérica. 
Shapiro-Garza, Elizabeth. 2013. Contesting Market-Based Conservation: Payments for Ecosystem Services as a Surface of Engagement for Rural Social Movements in Mexico, Human Geography 6(1), p 134-150

\section{Introduction}

On January 31, 2003, over 100,000 campesinos converged on the central plaza in Mexico City, the heart of the federal government and the nexus for social protest in that country, with numbers and directed purpose not seen since the agrarian reform movement of the 1930s (Carlsen 2003). A coalition of twelve peasant and indigenous organizations, ;Movimiento el Campo no Aguanta Más! (MECNAM), translated as “The Countryside Can't Stand Anymore!” had coalesced in response to the continued impacts of the neoliberal agriculatural policies of the 1990s on rural communities. They gathered that day to demand the renegotiation of the agricultural chapter of NAFTA and to force the Mexican state to, "Acknowledge the fundamental cultural role of agriculture and to break with the ideology that 'development' means to empty the countryside of farmers" (UNORCA 2007).

After a series of increasingly dramatic protests and prolonged negotiations, the government of then president, Vicente Fox, agreed to form MECNAM-headed working groups to discuss which rural policies would be addressed and how. The leaders of the environmental working group focused much of their efforts on pushing for the reform and expansion of a newly implemented federal Payments for Hydrological Services program that provided rural landholders in zones of water scarcity financial incentives for forest conservation. The end product of these negotiations the Acuerdo Nacional para el Campo (National Agreement for the Countryside), codified a number of groundbreaking concessions, including an agreement to form a second national PES initiative and to allow MECNAM representatives to serve on the design committee.

At face value, it seems strange that a rural social movement dedicated to combating what they themselves defined as "neoliberal policies" would so thoroughly embrace a market-based conservation program that proposed to privatize and commoditize the functions of rural ecosystems. However, the MECNAM representatives brought to the new program's design committee a very different conception of PES - as a recognition by Mexico's federal state and urban society of the valuable role of campesino environmental stewardship and an economic support to allow these stewards to remain on the land. The direct involvement of MECNAM in the design of the new PSA-CABSA program had a significant impact on its conformation that reflected this vision of revaluing the rural: the inclusion of agroforests and sustainably managed timber lands; requirements for self-defined forest management plans; provision of dedicated funding for technical assistance; and the training of local extensionists. However, perhaps the most profound impact of MECNAM's involvement in program design was in altering the policy makers' understanding of PES. They introduced a profoundly distinct vision of the inevitable connection between the production of "nature" and the cultural reproduction of its rural stewards that was in direct opposition to the market-based logic which constructs nature is divisible into autonomous economic units that can be assigned a monetary value, sold and traded. In doing so, these rural social movements directly contested the neoclassical economic theories that are the 
foundation of PES, shifting the policy discourse that positions these payments as market-based financial incentives given to rational actors who would otherwise deforest toward a vision and practice of PES as societal compensation for the forest stewardship of campesinos.

This study is based on a multi-sited ethnography of the Mexican national PES programs. Methods included extensive interviews in Mexico and the United States with the actors primarily responsible for designing and implementing the Mexican PES program ( $N=73)$, semi-structured interviews with project participants in 32 rural communities in the Mexican states of Jalisco, Colima, Guerrero and Oaxaca $(\mathrm{N}=102)$, discursive analysis of project-related documents, summary statistical analysis of national demographic and geographic databases, and observation of national and international policy meetings. Fieldwork was begun in October of 2005 and is ongoing.

This article examines the process through which a rural social movement in Mexico was able to redefine the market-based narrative of PES, the historical and political context that provided them a window of opportunity in which to engage a national PES policy, and the ways in which this engagement led to a hybridization of the policy itself. I position this analysis in context of the global project of "grabbing green", the focus of this special issue, as an example of the 'frictions' that can inhibit and even partially reverse the logic of the seemingly inexorable rise of market-based conservation policy and projects.

\section{Market-Based Conservation as a Useful Surface of Engagement}

In contesting the market-based logic of PES, MECNAM employed rich narratives grounded in the specific imaginaries of rural Mexico: references to campesinos as children of ever-sustaining maize, the power that results from mestizaje (racial and cultural mixing) that is part of Mexican national identity, and the undying ethos of the Mexican Revolution. However, it is important to recognize and situate these narratives in the context of broader discourses on the role of peasants in environmental stewardship that had been and continue to be generated by national and international rural social movements. .

The early 1990s saw a global rise in regional, national and transnational rural social movements. The reasons posited for this expansion include the harsh repercussions of the neoliberal agricultural policies first implemented in the 1980s, the openings presented by the transition to democracy in many developing countries, and the decline of the more traditional forms of political representation such as unions and political parties (Escobar \& Alvarez 1992; Deere \&Royce 2009). Latin American rural social movements are some of the largest and most active in the world, from national-level organizations such as the Movement of Rural Landless Workers (MST) in Brazil to regional organizations such as the Latin American Coordinator of Rural Organizations (CLOC) and the transnational La Vía Campesina (Wolford 2007; Wolford 2008; Baletti et al. 2008; Deere \&Royce 2009; Borras 2012). These movements are highly networked and share many common dialogues, including critiques of neoliberal policies in 
agriculture, a commitment to social justice, and the promotion of an alternative vision of development that encompasses sustainable development, agrarian reform and food sovereignty (Deere \& Royce 2009; Borras 2012). McMichael (2006) has characterized the "global agrarian resistance" as challenging the dominant framing of "development" in four ways:

"First, it inverts the current development explanandum, focusing attention on poverty as an outcome of, rather than a point of departure for, development (neoliberal style). Second, and related, it challenges the development telos of depeasantization, revalorizing rural cultural-ecology as a global good. Third, it subverts the subjective focus of development on individual responsibility by reasserting a political culture of solidarity. And fourth, it practises a multiperspectival politics, challenging the single-point perspective of the official development narrative." ( $p$ 472)

The environmental narratives employed by MECNAM were themselves a combination of home grown, place specific representations of rural reality and constructions that incorporated or built upon the narratives of these broader social movements. The international network of rural social movements has often contested what they view as a perverse and misguided focus on the intrinsic value of "nature" with no recognition of the intrinsic web of human construction or sustenance, others have found ways to appropriate these narratives to better fit the constraints and rural realities of the global south. As one example, Martinez-Alier (1995) found that, "There is at first sight a great distance between local movements and global issues. However, if we look a the defense of agricultural biodiversity...we notice an interesting phenomena: the use of global environmental ideas for local fights." (p. 88).

A number of scholars of Mexican rural social movements have theorized about the instrumental work such environmental narratives can accomplish, "against forces that seek to wrench [the campesino community] and the indigenous community, from whatever control of natural resources that they still hold - land, in the first place, but also biodiversity, forests, water, energy production and other raw materials" (Pickard 2004, p. 3). In his discussion of what he terms "ecological neo-Zapatismo", Victor Toledo (2006) reflects on the fact that the Zapatistas and other indigenous and rural movements have adopted the language of "sustainability", but that in doing so they are, "projecting beyond its most common meaning," (p. 3) to a concept that is encompassing of the necessity of human intervention to maintain the health and productivity of "nature". Mexican scholar, Enrique Leff (1998), is more explicit in his explanation of the basic utility involved in rural social movements taking on environmental rhetoric, claiming that, "The displacement of traditional human rights for [a rhetoric of] environmental rights... [allows them to discuss] the rights to self-manage their conditions of existence, which implies a process of reappropriation of nature as a basis for their survival and condition to generate an endogenous and self-determined process of development." (Leff 1998, p. 70). 
I believe that in mapping the evolution of the Mexican national PES program we can begin to see how, in this particular place and time, rural social movements employed PES as a "useful surface of engagement" (Escobar 1999, p. 13), as a site of contestation with the federal state, international lending institutions and conservation NGOs. My research documents the processes through which social movements in Mexico adopted and effectively 'hybridized' PES as a rhetorical and conceptual tool to capture at least some of the "value", fictitious, imaginary or otherwise, produced through the national PES programs.

\section{The Mexican National Payment for Ecosystem Services Programs}

Part of the larger global trend toward market-based environmental policies and programs (See the introduction to this special issue), payments for ecosystem services provide financial incentives to land owners to alter management practices in ways that increase the provision of functions of ecosystems that are directly beneficial to humans. The ecosystem services most commonly associated with PES initiatives are hydrological services, such as water purification and increased filtration into the water table or mitigation of flooding, biodiversity conservation, scenic beauty and green house gas sequestration. Although most PES initiatives are "marketlike" in that participation is voluntary, they provide incentives for conservation vs. penalties for degradation and contracts stipulate that payments are conditional on the conservation or improvement of the targeted ecosystem, few actual "markets" for ecosystem services have emerged, with most programs starting and remaining as subsidy programs by state or national governments or as part of larger projects of international conservation organizations (Wunder 2007).

Mexico's federal PES programs are the largest of only four other national-level PES initiatives in the world: Costa Rica's national PES program, China's Sloping Land Conversion Program, and the Conservation Reserve Program in the United States (Sanchez Azofeifa et al. 2007; Bennett 2008; Alix-Garcia et al 2012). Though their configuration has morphed over time, in their first years of implementation the Mexican programs were comprised of two federally funded branches: the Payment for Ecosystem Services-Hydrological (PSA-H) and the Program for the Development of Markets for the Ecosystem Services of Carbon Sequestration, the Derivatives of Biodiversity, and to Promote the Introduction and Improvement of Agroforestry Systems (PSA-CABSA). Both programs are administered by the Mexican National Forestry Commission (CONAFOR). Between 2003 and 2011, approximately 3.2 million hectares of forested land were entered into the programs and more than US\$489 million in Mexican federal funds were distributed to 5,967 communal or smallholder private property participants (CONAFOR 2012).

The first iteration of the national PES initiative, the PSA-H program first implemented in 2003, was strongly influenced by the discourse of international conservation NGOs and multilateral lending institutions that promoted market-based environmental policies a more 
efficient and effective than previous command and control regulatory approaches (McAfee \& Shapiro 2010). The initial proposal for a national level PES program Mexico's Strategic Forestry Program 2025, a product of a 2000-2001 collaborative planning group made up of actors from the Inter-American Development Bank (IADB), the Finnish government and the Mexican Secretariat for the Environment and Natural Resources (SEMARNAT) (CONAFOR 2002). The proposal notes that Mexico's diverse and extensive forests offer enormous potential for carbon sequestration and a "comparative advantage" for biodiversity prospecting given the diversity and extent of its forests. However, this formative document, anchored by the conceptualization of PES as a market-based conservation solution, makes little mention of likely socioeconomic effects.

The design of the first PES program was led by a group of economists and is clearly based on neoclassical economic principles. The initial design team was made up of members of the Department of Policy and Environmental Economics at the National Institute of Ecology (INE), a federal environmental research agency, and economists from the Mexican Universidad Iberoamerican and Centro de Estudios y Docenia Económica and from the University of California, Berkeley, with the World Bank involved in an advisory capacity (Alix-Garcia 2005). The Bank's Mexican office also formed an advisory committee of academics and representatives from environmental NGOs, foundations, and municipal officials with PES experience, but the committee had little direct impact on policy formation (Muñoz-Piña 2008).

The final design of PSA-H policy was a mix of market-based environmental measures, strongly imposed federal control, and both conservation and poverty-alleviation criteria (McAfee \& Shapiro 2010. It is very clear that the original designer's intention was for the program to serve as "start-up funding" for landholders who would, after the 5 year program contract ended, find way to sell the ecosystem services of their conserved forest on open markets (McAfee \& Shapiro 2010). To further these ends, they established two selection criteria intended to ensure demand and target the program to areas with the greatest potential for the formation of actual markets for hydrological services: 1) location upstream from a population center $>5,000 ; 2$ ) location in recharge zones of overexploited watersheds.

Payment rates, which the design team had proposed be established based on the average opportunity cost of forest conversion to corn production, were instead, rather arbitrarily, based on the size of the budget. They were set at US\$36.40 per hectare/year for cloud forest because of their supposed superiority at producing "hydrological services", and US\$27.30 per hectare/year for other forest types. Five-year program contracts were signed with forest land owners, with annual payments made contingent upon verification through remote sensing analysis or site visits that no forest cover had been lost in the enrolled property. Lands managed for timber or agroforestry (crops grown under the shade of trees) were not allowed and the program contracts required that landowners take a "no-touch" approach to their forests, limiting all access and use of forest resources. As will be discussed in more detail below, this rather simplistic approach to 
both conservation and poverty alleviation was to be challenged with rural social movements fought their way onto the design committee of a second national PES program, PSA-CABSA.

Thus far, funding for the PES programs has come almost entirely from the Mexican federal government, albeit with an infusion of a US\$45 million loan from the World Bank and a US\$15 million grant from the Global Environment Facility (GEF) in 2007 that were meant to foster the development of true markets for the ecosystem services produced. Markets for the ecosystem services produced by program participants have largely failed to materialize and the program has for all intents and purposes become yet another federal rural subsidy program (for a more detailed analysis of the causes of this "market failure" see Shapiro-Garza Forthcoming).

\section{Rural Social Movements in Mexico}

As was mentioned earlier, the assault on the market-based principles of the original national PES program was lead by a coalition of rural social movements that coalesced as MECNAM in 2003. In this section I explore the history of rural social movements in Mexico and discuss the convergence of economic crisis and political opening that lead MECNAM to organize and provided the opportunity, unheard of the history of agrarian mobilization in that country, of directly negotiating the terms of a federal level rural policy. Seizing this opening, MECNAM was able to insert their own vision of "conservation" and "poverty alleviation" into the policy design of the second PES program and into the hearts and minds of the policy makers.

From 1929 to 2000, Mexican politics were dominated at all levels by the corporatist rule of the Partido Revolutionario Institutional (PRI - Institutionalized Revolutionary Party). This dominance translated into pervasive, authoritarian clientelism, "the manipulative interplay of persuasion and coercion" (Hellman 1994, p. 127). In rural areas this clientelism meant vote buying, funneling of rural social services and aid through local PRI power brokers referred to as caciques, incorporation of social groups into state-controlled "movements", and active and brutal repression of any political opposition or non-state sponsored collective action (Fox 1994; Hellman 1994; La Botz 1995). In the 1980s, shaken by the economic crisis of 1982 and the loss of faith occasioned by the poor state response to the 1985 earthquake in the capital of Mexico City, the dominance of the PRI began to be slowly but successfully challenged both by reformers from within and social activists from without (Fox 1994; Preston \& Dillon 2004). This period marked the rise of a strong network of civil society organizations and independent social and environmental movements in Mexico.

This corporatist dominance of the PRI party at all levels of Mexican politics led to a continual, primarily covert suppression of social activism. As their name, the Institutionalized Revolutionary Party, implies, PRI leaders were masters at "institutionalizing" political collective action. Unions, cooperatives, and political organizations were allowed to form, but only with the sanction and very close supervision of the PRI party. Rebellious groups who spurned the clientelism of the PRI system were often violently repressed (Hellman 1994; Fox 2007). The PRI 
party's dominance of civil society did wax and wane to some extent throughout the term of their rule, but it also evolved and became more sophisticated as the years passed. Hellman (2008) describes a particularly "nasty twist" of president Echeverría, who ruled in the name of the PRI from 1970-1976, as being, "the invention of peasant and workers' organizations that carried the names of existing militant peasant organizations but which were headed by people passionately loyal to Echeverría." (p. 69). The PRI-sanctioned organization of rural workers and peasants is called the Confederación Nacional Campesina (CNC - National Peasant's Confederation) (Hardy-Raskovan 1984; MacKinlay 1996). Athough it no longer entirely dominates rural politics in Mexico, the CNC still holds enough control among segments of the rural population that the Fox administration was able to use the organization to, on some issues and occasions, divide and conquer the MECNAM coalition (Fox 2007, p. 344).

The PRI began to lose its political stranglehold in the mid-1980s as the process of democratization and the growth of a relatively independent civil society developed. As the avenues for open political protest and active engagement of civil society organizations became available, the campesinos of México have devised various forms of resistance to the decreasing state support for small-scale, peasant production and the devaluation of their way of life brought about by structural adjustment policies and the aftermath of other neoliberal policy interventions such as NAFTA. A number of organized campesino movements were formed in the late 1980s and early 1990s, from organized armed rebellion in Chiapas and other southern states (Collier \& Lowery Quaratiello 1994), to the resurgence of rural labor unions (MacKinlay 1996), to the organization of farmers' commodity cooperatives representing production as diverse as corn and coffee (Acuña Rodarte 2003; Aranda Bezaury 2003). These rural social movements have attempted to fill the gaps left by the withdrawal of state by replacing direct state price supports and services with cooperatives, state credit agencies with credit unions such as that of the $E l$ Barzón alliance, and corporatist membership organizations such as the $\mathrm{CNC}$ with more radical, independent associations of rural producers. Some of the most successful of these autonomous campesino organizations include the National Marketing Association of Rural Production (ANEC) and the National Union of Autonomous Regional Peasant Organizations (UNORCA), not to mention one of the most militant and influential of these movements, the Zapatista Army of National Liberation (EZLN) in the southern state of Chiapas.

As mentioned above, rural social movements in Mexico have become adept at appropriating environmental and social-liberal rhetoric (Bray 1997; Stolle-McAllister 2005; Harvey 2005). A discursive construct commonly employed by campesino organizations in Mexico and throughout Latin America is that of revalorización del campo (revaluing the rural), a call for political leaders to recognize the environmental, cultural and economic benefits provided to society through traditional rural stewardship and the integral, co-production of "nature". These movements have employed the concept of revaloración to counter the dominant narrative that has pervaded Mexican politics since the 1980's; that "development" must mean the industrialization of agricultural production and the movement of peasants into urban areas, their labor being more efficiently allocated to industrial production or the service sector. As Mexican 
and Central American campesino organizations proclaimed in the 2004 Manifiesto de Xochimilco, "You will not conserve nature by depopulating the countryside... To restore lost resources and equilibrium, what is missing is the restoration of a sustainable rural economy, capable of use without destruction." (CMDMIRP 2004, Point 12). This narrative, which attempts to make explicit the "value" of campesino environmental stewardship, was to dovetail nicely with the conceptual construct of PES as rural social movements rhetorically transformed the motive for these payments from an incentive to bribe potential environmental degraders into a financial recognition of value of and support for keeping peasant stewards on their land.

\section{Hybridization of the PES Programs by Rural Social Movements}

As I mentioned in the introduction, the MECNAM coalition of rural social movements and organizations that coalesced in 2003 in coincidental conjunction with the implementation of the first of the national PES programs, was to have a have specific and significant impacts on the both the conformation of the policy and the ontological rationale of the policy makers.

UNORCA, a coalition of campesino organizations that first formed in the mid-1980s, was primarily responsible for motivating the wider union of campesino organizations into the MECNAM coalition starting in the year 2000 (UNORCA 2007). When the first national PES program, PSA-H, was introduced in 2003, MECNAM was just gaining enough critical mass to begin to make overarching demands of the federal government (Rubio 2007). Although not all MECNAM leaders agreed that the movement should embrace PES, the reform and expansion of the PSA-H program was to become the cornerstone of the movement's environmental agenda.

Some members of the MECNAM coalition, including UNORCA, originally denounced the national PES program, equating these market-based mechanisms with other "neoliberal" policies that could only disempower the rural poor. However, some of the organizations that were initially wary of PES were later integrally involved in promoting the program and the concept. UNORCA had been amongst a number of the MECNAM constituent organizations that had, in the month before the 2003 protests in Mexico City, led a protest against market-based conservation measures being implemented in the Lacandon region of the state of Chiapas, calling bioprospecting agreements, ecotourism and the commercialization of non-timber forest products, "A new form of plundering the lands and resources of indigenous communities by private interests and transnational companies." (UNORCA 2002). And yet one of UNORCA's leaders agreed to serve on the PSA-CABSA design committee, and by the time of the organization's national level meetings in 2009, "environmental services providers" were counted among their 2,792, "regional and grass-root" constituent organizations (UNORCA 2009). It is important to recognize that this apparent change of heart by UNORCA and other MECNAM organizations may not signal a complete acceptance of PES, but more a means of capturing the, "perhaps scarce but not unimportant monetary resources that circulate in the rural economy." 
(Lindemann 2006, p. 55) while still maintaining relative autonomy from the influence of the federal state.

As mentioned in the introduction, after a series of MECNAM-led large and dramatic street protests at the beginning of 2003, the administration of President Vicente Fox agreed to negotiations in which all federal rural policies would be reviewed by MECNAM working groups. Although not granted the power to change policies, these groups would be spaces in which movement representatives could negotiate directly with state agencies. Because the Ministry of Finance had officially designated the new PES program as a rural subsidy, it too was open for review (Alix-Garcia 2005). The MECNAM Environment and Rural Development working group developed a report based on their negotiations that listed six basic, "proposals for valuing the environmental functions of campesino agriculture." (Marielle \& Aguilar 2003, p. 1). Proposal number one called on the Mexican state to, "revalue the multiple environmental, social, economic, and cultural functions that campesinos carry out as guardians of our natural resources." (Ibid, p. 2). The report claimed that rural poverty and emigration was weakening the ability of campesino families and communities to continue to steward the country's natural resources, and argued that, in order to ensure that this traditional stewardship continued, the state should revalue campesino labor in a way that was, "not just words and promises, but which establishes mechanisms of economic compensation." (Ibid, p. 2). Not surprisingly, one of the primary policy foci of the working group was the expansion and reform of the recently implemented federal PSA-H program. The reforms that they advocated for included restricting the number of private landholder participants and instead targeting economically marginalized ejidos and indigenous communities, raising per hectare payments, and including productive forest ecosystems such as sustainably managed timber and shade grown coffee (Alix-Garcia 2005). MECNAM continued their protests and direct negotiations and, after some bureaucratic and political resistance, US\$9 million in federal funding was set aside for a second PES program the total allocated to the PSA-H program.

In April of 2003, then President Fox signed the Acuerdo Nacional para el Campo (National Agreement for the Countryside), that codifying the agreements reaches with the MECNAM-affiliated working groups (Diario Oficial de la Federación 2003). Though CONAFOR initially resisted, a committee was formed to design the second PES program. The committee was made up of six representatives from MECNAM's civil society organizations as well as members from CONAFOR, the original PSA-H design team, and two government ministries. As one of the MECNAM representatives said, this committee, "was supposed to be a dialogue that combined the experience of government agencies and civil society organizations to create a program with real impact." (Interview June 16, 2006).

A number of the federal policy makers who were forced to negotiate the terms of the second PES program have admitted that they at first perceived the MECNAM representatives as mercenaries intent on hijacking an environmental incentives program to alter it to yet another federal rural subsidy for their constituencies. The MECNAM representatives I interviewed admitted that they did see the potential for PES program funding to fill some of the holes left 
after the withdrawal of rural production subsidies, technical assistance and price supports the resulted from NAFTA and the multiple rounds of structural adjustment initiatives in the 1980s and 90s (Marielle \& Aguilar 2003). However, these leaders also viewed their positions on the design committee as a chance to alter both the narrative and the policy practices surrounding PES in Mexico as well as contributing to a larger project to "revalue the rural" by framing PES as a recognition by the federal state and society write large for campesino's contributions to environmental stewardship. As one MECNAM leader expressed it, PES is:

"A new type of relation within a country and between countries. It is not just about sales and monetary gains, it is new a form of relationship: between the city and the countryside; industries and campesinos; developed countries and undeveloped countries; regions that are producers of waste and those that are producers of oxygen." (Interview November 22, 2005)

This vision of PES, not as an opportunity to introduce market-efficiency into conservation, but as a renewed recognition of the essential relationship between the traditional rural and the industrialized urban, is strikingly distinct from that of the original PSA-H program design team and it was to have very specific repercussions in the policy design of the second PES program.

The design committee for the new PES program included representatives from CONAFOR, INE, SEMARNAT, the National Water Commission (CNA), two coffee producer associations (CNOC and CEPCO) two community forestry organizations, Mexican Network of Peasant Forestry Organizations (Red-MOCAF) and the National Union of Community Forestry Organizations (UNOFOC -), a recently created coalition of organizations implementing PES programs in the state of Oaxaca (SAO), and UNORCA the previously mentioned national network representing campesino and indigenous organizations..

There had been an early and persistent political focus at the federal level on employing the PES program, at least rhetorically, as means to address rural poverty. The link between PES and poverty alleviation, as conceived by the program's original designer and the executive branch that was to become one if its greatest champions, is very direct. According to this view of PES, contracts are signed with poor rural land holders to abandon any use or management of their forest. The infusion of cash reduces poverty and the change of land use practices conserves forests, which in turn produces ecosystem services. This simplistic approach fails to take into account the complex, multi-faceted and interlinked causes and solutions of both poverty and environmental degradation.

The representatives from MECNAM introduced subtler conceptualizations of both "conservation" and "poverty alleviation" into the dialogue of the PSA-CABSA design committee that were to have substantial impacts on the policy itself. This understanding of inextricable web of relationship between the ecological and social systems of rural Mexico was articulated in an evaluation of the PSA-H program published by a national level research NGO linked with community-based forestry issues and initiatives and to which a number of MECNAM leaders are 
connected, the Mexican Sustainable Forestry Advisory Committee (CCMSS). The report states that, the PSA-H program promotes "rent-seeking" behavior in participants because it, "Does not require clearly defined actions and responsibilities in relation to forest management." (MerinoPérez et al. 2004 p. 5). As a MECNAM representative on the PSA-CABSA committee member stated, "The PSA-H program did not have a great impact on the communities where they were implemented because there was no requirement that they actively manage [the forest in the program], only that they not touch it." (Interview June 16, 2006). The CCMSS report warns that lack of requirements for active forest management makes enrolled forest, "Even more vulnerable than those that are managed for commercial production," and that the no-touch provisions could, over a long period, "Contribute to the process of abandonment of the forest and the people who live in forested regions." (Merino-Pérez et al. 2004, p. 6).

MECNAM representatives brought to the PSA-CABSA negotiations table this view that "management" of forest ecosystems for the production of both ecosystem services and rural "poverty alleviation" is not antithetical to the conservation of forests and the ecosystem services they produce, but is in fact necessary to achieve either. This clashing of two distinct conceptualizations of the meaning and means of PES translated into a number of specific policy recommendations introduced by the MECNAM representatives and adopted into the PSACABSA rules of operation: requirements that participants develop active forest management plans, provision of designated funding for technical assistance to develop the plan and provide training in sustainable management practices, and the inclusion of highly managed agroforestry systems as eligible for forest conservation funding.

The representatives of the MECNAM recognized that rural communities face enormous financial and knowledge barriers in quantifying, monitoring and managing for environmental services and in creating or negotiating with existing market for the services produced. They also worried that the direct payment approach, with the annual payments from CONAFOR being deposited directly into the community treasurer's account with no stipulations as to how the funding would be spent, would do little to promote true and lasting community development. As the CCMSS report concludes, "Compensation with the PSA-H program is limited to economic payments, with no consideration of other types of compensation that various service users could support, such as: access to training and technical assistance, preferential markets, certification, etc." (Merino-Pérez et al. 2004, p. 9). The MECNAM members argued for and won specific funding for technical assistance for development of management plans and for training of local extensionists. While these may seem like small changes, they represent an attempt to turn the simplistic notions of poverty alleviation first proposed by the designers of the PSA-H program and later supported by Mexico's president into self-defined, meaningful and long lasting rural development.

The process of combining these two very distinct approaches and perspectives into hybridized whole was a long and contentious process: more than thirty meetings were held before the new PES program's rules of operation were finalized in 2004. After the first year, funding for the program was halved every year from 2004 through 2006. Though CONAFOR 
claimed that these cuts were due to low enrollment rates, it had never throughly promoted the program. As one of the MECNAM representatives from the design committee stated when asked to interpret this lack of administrative support, he stated that it was, "a form of vengeance on the part of the government because the campesino movements forced them to the table and made them make concessions." (Interview, June 29, 2006)

In 2006 CONAFOR consolidated PSA-H, PSA-CABSA, and several other programs under the rubric of a single program, ProÁrbol, ostensibly to streamline administration. The PSA-H and PSA-CABSA oversight committees were disbanded. The new oversight committee selected for new ProÁrbol program represented a much less diverse, and subsequently less contentious group, with representatives from CONAFOR, SEMARNAT, and the "social, forest industry, forest management professional and academic" spheres but, no members from the original PSA-H National Institute of Ecology (INE) design team nor from the MECNAM coalition (CONAFOR 2006, p 5). However, the Mexican office of the World Bank incorporated the disenfranchised MECNAM committee members into a PES policy advisory group, and while its members have no voting power in the new PES program, it continues to meet with the CONAFOR administrators of the program three times a year and policy changes proposed by the group are still being incorporated into the yearly rewrite of the program rules.

The MECNAM-led reforms agreed upon in the 2003 National Agreement for the Countryside were for the most part weakened or subverted entirely by the administration of then president Vicente Fox and the federal agencies it oversaw (Rubio 2007). The PSA-CABSA program has been characterized as the exception by many involved. As one of the leaders of the MECNAM stated, this PES program was, "one of the few processes in which the federal government accepted a multilateral process with campesino and civil society organizations." The same leader also stated that he viewed the involvement of MECNAM in the design process for the PSA-CABSA program as having had three more profound impacts on the mentality of the policy makers: "That it was accepted that active management is not antithetical to conservation; that the mulitifunctionality of ecosystems was recognized; and that, ultimately, it is not just a payment but a true contract." (Interview, June 29, 2006).

While I have detailed above the ways in which participation of MECNAM members in the PSA-CABSA design process led to very specific changes to policy, this interaction also brought about a certain amount of hybridization of "bureaucratic knowledge" as well (Rocheleau 2008). In interviews with the CONAFOR administrators on the PSA-CABSA design committee it became clear that the involvement of MECNAM's representatives had had a lasting impact on their conception of both the function and functionality of PES.

In an interview with the national director of the CONAFOR PES programs, he stated that his interaction with the MECNAM had radically changed his views about the role of the rural poor in environmental degradation. He said, "Before, I thought of ejidos as only resource degraders. I learned that often they degrade only because they don't have resources to invest in adequate management." (Interview Nov. 17, 2006). He also claimed that his interaction with MECNAM had changed his view on the very mechanism of PES, that, "You can't just give out 
the money and expect that it will cause conservation," but that active engagement of intermediary NGOs at the community level along with funding for technical assistance and monitoring are crucial. (Interview Nov. 17, 2006). These changes in perspective by program administrators were key in maintaining the innovated policy mechanisms introduced by MECNAM after they had left the negotiation table.

While MECNAM eventually lost its seats on the design committee, the distinct vision of PES that they had introduced continued to affect PES policy. When the PSA-CABSA and PSA$\mathrm{H}$ programs were integrated in 2006, instead of cutting the innovations introduced by MECNAM representatives, they were brought into the rules of operation for all PES programs: requirements for forest management plans and targeted funding for technical assistance and capacity building. Although the portion of the PSA-CABSA program that specifically targeted agroforestry systems was cut, in 2010, CONAFOR agreed to allow enrollment into the PSA-H program of a limited number of hectares of actively managed agroforestry systems or timber lands in the regrowth phase as long as a sustainable harvest management plan was in place.

Although the MECNAM coalition eventually disintegrated as the result of internal conflicts and external pressures, the campesino movement in Mexico remains strong. In the beginning of February 2008, the majority of the member organizations of MECNAM joined together along with labor and student organizations on a march to Mexico City's Zocolo to commemorate the MECNAM protests five years earlier. Shouting, "Sin maíz, no hay pais!" (Without corn there is no country!), these campesinos again demanded the renegotiation of the agricultural chapter of NAFTA and an end to the government's neoliberal politics. As the one of the coalition's leaders proclaimed, “The imperialists want to burden their own crisis on Mexico's back and it is for this reason that [President] Calderón does everything possible to pass structural reforms. But the government forgets that we are an invincible people, that we are the children of maize and that we will only die when the sun dies." (Pérez et al. 2008, p. 2)

\section{Conclusions}

While never idealizing campesino land management nor essentializing their role to that of noble savages or environmental angels, MECNAM representatives brought to the PSA-CABSA policy negotiations a discourse that represented these small holder rural producers as knowledgeable and necessary stewards protecting their forest from pests, disease, fire, illegal logging and poaching while at the same time relying on these natural systems for their physical sustenance and cultural reproduction. These actors also introduced a more holistic definition of "ecosystem services" and their necessary co-production with rural communities that was to have profound and lasting impacts on the specific design of national PES policies in Mexico and on the policymakers themselves. This conceptualization of PES and what it should accomplish was at the base of the policy reforms introduced by MECNAM representatives: allowing enrollment of highly managed agroforests and timber lands; requiring that participants develop and execute 
forest management plans; and providing dedicated funds for technical assistance and training of local extensionists.

In engaging with the national PES programs, MECNAM was, on the surface, simply playing the age-old political game of bringing federal subsidies home for their struggling rural constituents. In fact the battle had much more profound implications for redefining and reallocating both the blame and the value produced through PES. While the concessions they won in policy design may seem small, they represent a substantial shift away from the standard, market-based ontology of PES. In the discourse of PES represented by international environmental NGOs and multilateral lending institutions, and reproduced by the designers of the original national PSA-H program in Mexico, payments represent a bribe to rational economic actors who would otherwise clear cut their forests for more lucrative uses and as a first step in the process of separating, dividing, and assigning and economic value to "ecosystem services" that can then be bought and traded on the market. In MECNAM's positioning of campesinos as necessary environmental stewards of rural ecosystems and PES payments as compensation for the labor and knowledge applied to protecting the forests that produce valuable local, regional and global services, MECNAM took one step further in the national and global movement to "revalue the rural".

Agrawal \& Sivaramakrishnan (2000) have applied Foucault's theories of "biopoltics" to a process they refer to as 'striation', the desire of the state to partition "the landscape into distinct domains of natural existence and productive economic relations." (p. 2), in an attempt to "rationalize the problems presented to governmental practice." (Foucault 2008, p. 73). But this process of disarticulation of natural vs. agrarian landscapes, while still possible (see Osbourne 2011), has encountered greater obstacles in Mexico than in other countries precisely because so much of the agriculturally marginal forestland that would later become of particular interest to conservationists was early allocated to peasant and indigenous groups to be held communally. Even after the 1992 reform to the constitution that allowed for privatization of communal lands, as of $200551.6 \%$ of Mexico's total territory and an estimated $80 \%$ of the country's forestland was held by núcleos agrarios (Bray et al. 2005; Appendini 2008). The predominant overlap of agrarian and "pristine" landscapes in Mexico has led to conservation strategies by both the state and environmental NGOs that explicitly recognize the concepts of "wise use" (i.e. communitybased conservation zones, biosphere reserves, etc.). Whereas in other countries the "occupation" of state-held protected or "natural" areas by peasants or indigenous groups who are granted some degree of access may be the norm, it is rarely recognized with legitimate or full land tenure (Ribot \& Peluso 2003). MECNAM's co-option of the PES programs might not have been as successful, nor the hybridization of the concept towards a representation as an economic support of traditional rural stewardship been so complete, if campesinos' tenure rights to the land on which ecosystem services are being produced did not have such strong historical and legal legitimacy.

In discussing the potential spaces for contestation of contemporary neoliberalism, Porter and Craig (2004) claim that, 
"Political activism matters, and spectacular street protest has certainly had an effect: but the costs of this kind of self-exclusion are specifically what this system is designed to raise. The alternative, clearly popular with third sector organizations and community groups, is to work 'included' within the system... to exploit the small openings made by participatory rhetoric and the ongoing need for popular legitimation." (Porter \& Craig 2004, p 417).

What becomes apparent from the history of the PSA-CABSA program is that the MECNAM members who pushed for a reformed PES program have employed both of these methods with some success, finding the program a "useful surface of engagement" (Escobar 1999, p 13) to assert the relevance and value of campesino environmental stewardship to the federal state and contest the basic premises on which market-based environmentalism is built: the definition of nature as separate from its cultural production and its divisibility into economic units that can be valued, sold and traded. Instead of choosing radical activism vs. working from the inside, these actors used both techniques with some success. It was the "spectacular street protest" and resulting negotiations in 2003 that pushed the Fox administration to form the second PES program and allow MECNAM representatives on the design committee. That, after two years, they were eventually denied voting rights and relegated to a World Bank-led advisory committee would seem to suggest that these rural radicals had been pacified with promises of "participation" only to be excluded from any position of power or influence. I would claim, however, that this particular "opening" for contestation was not "small", but that real and substantive changes in policy and perception were brought about through their participation. Though the MECNAM coalition was eventually to fracture, their representatives on the PSACABSA committee and the organizations and constituencies they represent continue to participate in both the radical political activism and to work with and even within the Mexican government at various levels.

Josefina Aranda of the coffee association CEPCO, one of the leaders instrumental in putting PES on the agenda of MECNAM, has said, "There are huge contradictions between the perspective of the neoliberals who promote [PES] programs from the World Bank, etc., and those of us from the Mexican countryside. The fact that we were both interested in developing payment for environmental service programs was just a lucky convergence of interest." (Interview November 30, 2005). What remains to be seen is just how "lucky" this convergence of interests will be for the rural communities of Mexico.

\section{REFERENCES}

Acuña Rodarte, O., T. Wise, et al. (2003). Toward and equitable, inclusive and sustainable agricultre: Mexico's basic grains producers unite. Confronting Globalization: Economic 
Integration and Popular Resistance in Mexico. Anonymous. Bloomfield, Connecticut, USA, Kumarian Press, Inc.: 129-148.

Adler Hellman, J. (2008). Mexican popular movements, clientalism, and the process of democratization. Latin American Social Movements in the Twenty-First Century. R. StahlerSholk, H. E. Vanden and G. D. Kuecker. Lanham, MD, USA, Rowman \& LIttlefield Publishers, Ltd.

Agrawal, A. and K. Sivaramakrishnan (2000). Introduction: Agrarian environments. Agrarian Environments: Resources, Representation and Rule in India. Anonymous. Durham, North Carolina, USA, Duke University Press. 1st: 1-22.

Alix-Garcia, J. M., A. de Janvry, et al. (2005). "An assessment of Mexico's payment for environmental services program." Retrieved August 12, 2007, 2007, from

ftp://ftp.fao.org/es/ESA/Roa/pdf/aug05-env_mexico.pdf.

Alix-Garcia, J. M., E. N. Shapiro, et al. (2012). "Forest conservation and slippage: Evidence from Mexico's national payments for ecosystem services program." Land Economics 88(4): 613638.

Almeida, P. D. (2007). "Defensive mobilization: Popular movements against economic adjustment policies in Latin America." Latin American Perspectives 34(3): 123-139.

Appendini, K. (2008). Interpreting property rights from below: The case of the PROCEDE program, Mexico. New Latin American Development Strategies in a Changing International and Political Context, Aalborg University, Aalborg, Denmark.

Aranda Bezaury, J. (2003). Peasant farmers in a global economy: the State Coalition of Coffee Producers of Oaxaca. Confronting Globalization: Economic Integration and Popular Resistance in Mexico. T. Wise, H. Salazar and L. Carlsen. Bloomfield, Connecticut, USA, Kumarian Press, Inc.: $149-170$.

Bakker, K. (2007). "The "commons" versus the "commodity": Alter-globalization, antiprivatization and the human right to water in the global south." Antipode 39(3): 430-455.

Baletti, B., T. Johnson, et al. (2008). "Late mobilization: Transnational peasant networks and grassroots organizing in Brazil and South Africa." The Journal of Agrarian Change 8(2-3): 290314.

Bartra, A. and G. Otero (2005). Indian peasant movements in Mexico: The struggle for land, autonomy and democracy. Reclaiming the Land. S. Moyo and P. Yeros. London, UK, Zed Books: 383-410.

Bennett, M. T. (2008). "China's sloping land conversion program: Institutional innovation or business as usual?" Ecological Economics 65: 699-711. 
Bobrow-Strain, A. (2004). "(Dis)accords: The politics of market-assisted land reforms in Chiapas, Mexico." World Development 32(6): 887-903.

Borras Jr., S. M. 2012. Agrarian change and peasant studies: changes, continuities and challenges - an introduction. Journal of Peasant Studies 36 (1):5-31.

Bray, D. B. (1997). La reconstrucción permanente de la naturaleza: Organizaciones campesinas y desarollo popular sustentable. Semillas para el Cambio en el Campo: Medio Ambiente, Mercados y Organizaciones Campesina. L. Paré, D. B. Bray, J. Burstein and S. Martínez. Mexico City, D.F., Mexico, Universidad Nacional Autónoma de México.

Bray, D. B., L. Merino-Pérez, et al. (2005). The Community Forest of Mexico: Managing for Sustainable Landscapes. Austin, Texas, USA, University of Texas Press.

Brown, K. and E. Corbera (2003). "Exploring equity and sustainable development in the new carbon economy." Climate Policy 3: S41-S56.

Burstein, J., G. Chapela y Mendoza, et al. (2002). Pago por Servicios Ambientales y Comunidades Rurales: Contexto, Experiencias y Lecciones de México. Pago por Servicios Ambientales en las Américas. H. Rosa: 1-51.

Carlsen, L. (2003). The Mexican farmer's movement: exposing the myths of free trade. Montevideo, Uruguay, Third World Institure. 2004: 7.

CMDMIRP (2004, September 7, 2007). "Manifesto de Xochimilco." Retrieved July 2, 2009, from http://www .cedrssa.gob.mx/?doc=453.

Cobo, R. and A. L. González Fernández (2004). El Nuevo Movimiento Campesino Mexicano. Coyoacán, DF, Mexico, Fundación Heberto Castillo Martínez, A.C.

Collier, G. A. and E. Lowery Quaratiello (1994). Basta! Land and the Zapatista Rebellion in Chiapas. Oakland, California, USA, The Institute for Food and Development Policy.

CONAFOR (2002). "Programa Estratégia Forestal para México 2025." Retrieved July 5, 2009, from http://www.conafor.gob.mx/portal/docs/subsecciones/normateca/PEF_2025.pdf.

CONAFOR (2006). Reglas de Operación de los Programas de Desarollo Forestal de la Comisión Nacional Forestal: Apoyos por Concepto de Servicios Ambientales C. G. d. P. y. Productividad, CONAFOR: $1-34$.

CONAFOR (2007). Estrategia para el Desarollo de Mercados de Servicios Ambientales. C. G. d. P. y. P. G. d. S. A. d. Bosque, CONAFOR: 1-68. 
CONAFOR (2012). Payments for ecosystem services in México. Ecosystem Services Working Group. P. Bauche Petersen. Duke University.

Deere, C. D. and F. S. Royce (2009). Introduction: The rise and impact of national and transnational rural social movments in Latin America. Rural Social Movements in Latin America: Organizing for Sustainable Livelihoods. C. D. Deere and F. S. Royce. Gainsville, FL, USA, University of Florida Press: 1-32.

Diario-Oficial-de-la-Federación (2003). Acuerdo Nacional para el Campo: Por el Desarrollo de la Sociedad Rural y la Soberanía y Seguridad Alimentarias. D. Oficial, SIEMEXICO.

Escobar, A. and S. Alvarez (1992). The Making of Social Movements in Latin America: Identity, Strategy and Democracy. Boulder, CO, USA, Westview Press.

Escobar, A., E. Bergland, et al. (1999). "Steps to an antiessentialist political ecology (and comments and replies)." Current Anthropology 40(1): 1-30.

Foucault, M. (2008). The Birth of Biopolitics: Lectures and the College de France, 1978-79. New York, NY, USA, Palgrave Macmillan.

Fox, J. (2007). Accountability Politics: Power and Voice in Rural Mexico. Oxford, UK, Oxford University Press.

Hardy Raskovan, C. (1984). El Estado y los Campesinos: La Confederación Nacional Campesina (CNC) Mexico City, DF, Mexico, Editorial Nueva Imagen.

Harvey, N. (2001). The political nature of identities, borders and orders: Discourse and strategy in the Zapatista rebellion. Borderlines \#18: Identities, Borders, Orders: Rethinking International Relations Theory. M. Albert, D. Jacobson and Y. Lapid. Minneapolis, MN, USA, University of Minnesota Press: 349.

Harvey, N. (2005). Zapatismo y sustentabilidad. La Jornada. Mexico City, Mexico.

Hellman, J. A. (1994). "Mexican popular movements, clientelism, and the process of democratization." Latin American Perspectives 21(2): 124-142.

Karriem, A. (2009). "The rise and transformation of the Brazilian landless movement into a counter-hegemonic political actor: A Gramscian analysis." Geoforum 40: 316-325.

L'Hospitalet, C. d. S. d. (2003). "El campo no aguanta más." Chichigua 5: 4-. Entrevista al mexicano Alberto Gómez Flores, de visita en nuestro país invitado por las ONGs catalanas, para presentar su campaña de Soberanía Alimentaria. Alberto Gómez es presidente de la UNORCA Unión Nacional de Organizaciones Regionales Campesinas Autónomas de México-, y representante delmMovimiento mejicano "El campo no aguanta más". 
La Botz, D. (1995). Democracy in Mexico: Peasant Rebellion and Political Reform. Boston, MA, USA, South End Press.

Leff, E. (1998). Saber Ambiental: Sustentabilidad, Racionalidad, Complejidad, Poder. Coyoacán, DF, Mexico, Siglo XXI Editores.

Leff, E. (2010). "Imaginarios sociales y sustentabilidad." Cultura y Representaciones Sociales 5(9): 42-121.

Leff, E., A. Argueta, et al. (2002). Más allá del desarrollo sustenible: La construcción de una racionalidad ambiental para la sustenabilidad: Una visión desde América Latina. La Transición hacia el Desarrollo Sustentable: Perspectivas de América Latina y el Caribe. E. Leff, E. Ezcurra, I. Pisanty and P. Romero Lankao. Mexico City, Mexico, Instituto Nacional de Ecología.

Lindeman (2006). "UNORCA and the financial dependence of producer organizations." Land Reform 2: 44-83.

Mackinlay, H. and H. C. de Gramont (1996). La CNC y el nuevo movimiento campesino (19891994). Neoliberalismo y Organizacion Social en el Campo Mexicano. Anonymous. Distrito Federal, Mexico, Plaza y Valdes: 165-238.

Marielle, C. and J. Aguilar (2003). Propuestas para valorar la función ambiental de la agricultura campesina. Mexico City, DF, Mexico, Groupo de Estudios Ambientales, A.C. (GEA): 6.

McMichael, P. 2006. Reframing development: Global peasant movements and the new agrarian question. Canadian Journal of Development Studies 27 (471-483).

McMichael, P. (2008). "Peasants make their own history, but not just as they please..." Journal of Agrarian Change 8(2/3): 205-228.

Merino Pérez, L., A. González, et al. (2004). El programa de pago por servicios ambientales hidrológicos: Revisión crítica y propuestas de modificación. Mexico City, Mexico, Consejo Civil Mexicano para la Silvicultura Sostenible, A.C.: 1-28.

Moyo, S. and P. Yeros (2005). The resurgence of rural movements under neoliberalism. Reclaiming the Land. S. Moyo and P. Yeros. London, UK, Zen Books.

Muñoz Piña, C., A. Guevara, et al. (2008). "Paying for the hydrological services of Mexico's forests: Analysis, negotiations and results." Ecological Economics 65: 725-736.

Muttoo Osbourne, T. (2011). "Carbon forestry and agrarian change: access and land control in a Mexican rainforest." Journal of Peasant Studies 38(4): 859-883. 
Peluso, N. L. (2007). Enclosure and privatization of neoliberal environments. Neoliberal Environments: False Promises and Unnatural Consequences. N. Heynen, J. McCarthy, S. Prudham and P. Robbins. New York, NY, USA, Routledge: 298.

Peluso, N. L., S. Afiff, et al. (2008). "Claiming the grounds for reform: Agrarian and environmental movements in Indonesia." Journal of Agarian Change 8(2): 377-407.

Pérez, M., C. Gómez, et al. (2008). Se agotan tiempos para el dialogo: campesinos. La Jornada. Mexico City, DF, Mexico: 1-2.

Pickard, M. (2004) Los efectos del Tratado de Libre Comercio de Norteamerica (TLCAN) sobre el desarrollo rural.

Porter, D. and D. Craig (2004). "The third way and the third world: Poverty reduction and social inclusion in the rise of 'inclusive' liberalism." Review of International Political Economy 11(2): 387-423.

Puricelli, S. (2008). Contradicciones y aportes del movimiento El Campo No Aguanta Más (2002-2004). Desafios de la Sociedad Rural a Despuntar el Siglo XXI: Economía y Política. I. L. Acosta Reveles. Zacatecas, Zac., Mexico, Universidad Autónoma de Zacatecas: 103-130.

Quintana, R. D. (2004). "El Campo No Aguant Más! Una apuesta hacia la construcción de una política pública incluyente para el México rural." El Cotidiano 19(24): 57-63.

Ribot, J. and N. L. Peluso (2003). "A theory of access." Rural Sociology 68(2): 153-181.

Rocheleau, D. E. (2008). "Political ecology in the key of policy: From chains of explanation to webs of relation." Geoforum 39: 716-727.

Sánchez Albarrán, A. (2007). El Campo No Aguanta Más. Mexico City, DF, Mexico, Universidad Autonoma Metropolitana Zacapotzalco.

Sanchez-Azofeifa, A., A. Pfaff, et al. (2007). "Costa Rica's pyament for environmental services program: Intention, implementation, and impact." Conservation Biology 21(5): 1165-1173.

Scott, D. and C. Barnett (2009). "Something in the air: Civic science and contentious environmental politics in pos-apartheid South Africa." Geoforum 40: 373-382.

Shapiro-Garza, E. 2013. "Contesting the market-based nature of Mexico's national payments for ecosystem services programs: Four sites of articulation and hybridization." Geoforum.

Sheridan, T. E. (1988). Where the Dove Calls: The Political Ecology of a Peasant Corporate Community in Northern Mexico. Tucson, AZ, USA, University of Arizona Press. 
Simonian, L. (1995). Defending the Land of the Jaguar. Austin, TX, USA, University of Texas Press.

Stahler-Sholk, R., H. E. Vanden, et al. (2008). Introduction. Latin American Social Movements in the Twenty-First Century. R. Stahler-Sholk, H. E. Vanden and G. D. Kuecker. Lanham, MD, USA, Rowman \& Littlefield Publishers, Ltd.

Stolle-McAllister, J. (2005). Mexican Social Movements and the Transition to Democracy. Jefferson, NC, USA, McFarland and Company, Inc.

Strawn, K. D. (2009). "Contemporary research on social movements and protest in Latin America: Promoting democracy, resisting neoliberalism, and many themes in between." Sociology Compass 3/4: 644-657.

Toledo, V. M. (2006). Ecología, Espiritualidad, Naturaleza. Morelia, Mexico, Jitanjáfora Ediciones.

Toledo, V. M. (2009). Ecología política, sustentabilidad y poder social en Latinoamérica. La Jornada. Mexico City, DF, Mexico.

UNORCA (2002) La Unión Nacional de Organizaciones Regionales Campesinas Autónomas (UNORCA), se opone al desalojo de la población campesina e indígena asentada en la región de Montes Azules, Chiapas.

UNORCA (2007). "UNORCA's Social Movements." Retrieved July 31, 2007, from http://www.unorca.org.mx/ingles/movementactivities.htm

UNORCA (2009). Reafirmamos nuestra autonomía y reforzamos la lucha contra la desigualdad. XI Asemblea Nacional de Delegados y Representantes, Mexico City, DF, Mexico, La Unión Nacional de Organizaciones Regionales Campesinas Autónomas (UNORCA).

Wittman, H. (2009). "Reframing agrarian citizenship: Land, life and power in Brazil." Journal of Rural Studies 25: 120-130.

Wolford, W. (2007). "Land reform in the time of neoliberalism: A many-splendored thing." Antipode 39(3): 550-570.

Wolford, W. (2009). "Everyday forms of political expression." The Journal of Peasant Studies 36(2): 411-415.

World-Bank (2007). "Current World Bank projects with PES components." Retrieved August 31, 2007, from http://web.worldbank.org/WBSITE/EXTERNAL/TOPICS/ENVIRONMENT/EXTEEI/0,,conten tMDK:20487983 menuPK:1187844 pagePK:210058 piPK:210062 theSitePK:408050,00.html 
Wroughton, L. (2008). "World Bank names countries for forest carbon fund." Retrieved June 25, 2009, from http://communities.thomsonreuters.com/Carbon/pages/print/posts/?bid=cc5b7f86fd9a-4d0e-aede-50372eace1a0\&mode=Full.

Wunder, S. (2007). "The efficiency of payments for environmental services in tropical conservation." Conservation Biology 21(1): 48-58. 